\title{
The Influence of the Greek Economic Crisis on FYROM Exports
}

\author{
Ljupco Davcev ${ }^{1}$ and Nikolas Hourvouliades ${ }^{*}$ \\ ${ }^{1}$ Faculty of Economics, Goce Delcev University, Stip, FYROM \\ ${ }^{2}$ American College of Thessaloniki, Greece
}

\begin{abstract}
According to the contemporary political and economic conditions, there is still an existing possibility for Greece to exit the Euro zone. If this scenario comes true, it will further decrease FYROM imports from Greece, as this will most probably result in the return of the Drachma with an assumed $50 \%$ devaluation to the Euro. On the other hand, FYROM exports Greece will become equally more expensive. The economic crisis which currently trembles our neighbour Greece has emerged as a new variable in the prediction and planning of economic activity along with main economic variables in the Macedonian economy. Analysis of the economic and trade relations between Greece and FYROM shows a steady decline during the last five years. FYROM exports to Greece in the first quarter of 2012 are at the lowest level in the history of trade relations between the two countries, at $€ 39 \mathrm{~m}$. Even worse is that the coverage of imports from Greece with exports from FYROM is only 25.2 basis points, which is also at the lowest historical level. This is a clear indication that FYROM is losing Greece, neighbouring country and EU member, as a significant business partner. This paper is trying to determine the potential effects on Macedonia economy due to the contemporary Greek crisis taking into consideration that our neighbour is one of the largest investors and trading partners of FYROM.
\end{abstract}

Keywords: Foreign effective demand; GDP growth;Income elasticity coefficient; FYROM exports growth rate

\section{Introduction}

This has been the fifth consecutive year (2013) that the Greek GDP is still falling, keeping the country in the deepest recession period of its modern history. The government has recently announced, in the last quarter of 2013, that a primary surplus has been achieved for the first time, after almost a decade that the country has had four times higher budget deficit than that allowed for Eurozone member countries. But the current situation in Greece after more than three years later is alarming. During the economic crisis Greece received an unprecedented financial aid from the European Union and the International Monetary Fund. Government also made huge cash savings in the budget, severing public wages and pensions and minimizing public expenditure. In the same fashion, the private sector has also taken the blown, since it is called upon to support the ailing public sector of the economy. Nevertheless, results have not yet met expectations and the country has cumulatively lost more than a quarter of its wealth during the past five years.

The Greek economy was not in an ideal situation even before the crisis. GDP in 2008 fell by $0.2 \%$; a year later it fell by another $3.1 \%$. In 2011, GDP fell by $7.1 \%$. The draft state budget for 2013 foresaw another year of crisis, specifically reducing GDP by an additional $3.8 \%$, but economic analysts believe that GDP will finally fall by $4.2 \%$ as a result of reduced economic activity. On February 2013 the Chairman of the Bank of Greece projected a $4.5 \%$ recession and $26 \%$ unemployment for the current year. The impact of unemployment is phenomenal: four years ago, the unemployment rate stood at $7.7 \%$ and has since been in continuous growth. In August 2013 it stood at $27 \%$ or more than quarter of the total active working population and latest announcements report a stable $27 \%$ in the end of 2013 . Government debt three years ago stood at $129.4 \%$ of GDP, and the end of 2013 it is expected at about $170 \%$.

FYROM exporters and Greek companies operating in the country during the last few years have strongly felt the effects of the Greek debt crisis. What is more important, the crisis is not appeased, but is gaining impetus. Direct result of the poor financial situation of Greece is the reduction in Macedonian exported goods and services. As the difficult economic situation escalates in Greece, FYROM exports are the most endangered in the aggregate economic cooperation between the two countries. The point here is on the most exported products, i.e. iron, steel, textiles, tobacco and marble. These five products count for about $55 \%$ of the total exports to Greece.

Likewise, Greek debt crisis has a negative impact on Greek investments in the country. Greek companies are expected to begin intensive efforts to extract profits from abroad, rather than reinvest in the business in the country, in order to distribute dividends to their shareholders in Greece. State statistics already show a declining trend in both export and direct investment in Greece in recent years. According to official records, in particular the office of financial and business affairs in Skopje, Greece in 2013 still stood as the largest investor in the country, followed by Germany, Serbia, Bulgaria and Italy.The report noted that the country's exports to Greece totaled around 188 million US dollars, while imports totaled 804 million dollars. According to Hellenic Statistical Authority, Greek exports to FYROM -excluding oil- totaled 255.7 million euros in the January-November 2012 period, up $1.14 \%$ from 2011, while imports totaled 156.4 million euros, up $1.88 \%$ over the same period, respectively. The value of bilateral trade transactions in the 11-month period totaled 412 million euros, up $1.42 \%$ from 2011 .

The economic crisis which presently shakes our neighbour has emerged as a new variable in the prediction and planning of economic activity along with main economic variables in the FYROM economy. This paper is trying to determine the potential effects on our economy from the economic crisis in Greece, considering that our neighbour is one of the largest investors and trading partners of our economy. The

*Corresponding authors: Nikolas Hourvouliades, American College of Thessaloniki, Greece, Tel: +30 2310 39838; E-mail: hourvoul@act.edu

Received October 23, 2013; Accepted December 16, 2013; Published December 19, 2013

Citation: Davcev L, Hourvouliades N (2013) The Influence of the Greek Economic Crisis on FYROM Exports. J Bus Fin Aff 3:115 doi:10.4172/2167-0234.1000115

Copyright: ( 2013 Davcev L, et al. This is an open-access article distributed under the terms of the Creative Commons Attribution License, which permits unrestricted use, distribution, and reproduction in any medium, provided the original author and source are credited. 
dominant part of the analysis will focus on determination of the future effects of the economic crisis in Greece, including FYROM's foreign effective demand.

\section{Literature Review}

The significance of exports on national economy and their relationship to GDP levels has been analysed by many empirical studies. The categorization of these studies varies depending on either the methods applied or the scope of geographical regions. As far as the methods are regarded, some articles try to distinguish causality links between exports and GDP as well as existence of co-integration, whereas other look into short term relationships that could help policy makers adjust their decisions. As far as geographical regions are concerned, there are studies that examine one country-domestic characteristics, whereas other cover multiple countries or economic zones that share common economic and political characteristics.

Another important issue that influences all variables is the country's monetary policy. The local currency, the Denar, is at a semipegged rate to the Euro and has been kept stable for the last decade or so. Until recently, the annual capital inflows were sufficient for the country to pay its debt and maintain the rate to the Euro. Current conditions however have raised the question of the future monetary policy of the country and the extend up to which the Euro peg can have more benefits than disadvantages.

According to a research by Nenovski et al. [1] the domestic economy of FYROM has been found to have some basic parameters, namely: a) the economy is heavily dependent on the only a few sectors (metals, textiles and agriculture), b) the movement of international prices has a great effect upon import and export goods, and c) the domestic demand on goods and services is relatively limited, discouraging the development of the economy.

In an earlier study by Kostoska and Petreski [2]on the state of competitiveness of the economy they claim that the country had an unsuccessful attempt to transition characterized by low growthrates and high unemployment. They also underline the dependence of the economy and its growth potential upon export competitiveness.

In a cointegration based analysis, Sharma and Panagiotidis [3] examine the case of India over a thirty year period 1971-2001 and fail to find convincing evidence of a Granger causality between exports and GDP or exports and investments. Interestingly enough Ramos [4] examines data from the Portuguese economy and also cannot prove causality between exports-imports and growth.

On the contrary, Konya [5]analyses a vast set of OECD countries and finds one-way and two-way causality in most countries between real exports and real GDP over a forty year period, with the exception six countries that do not have any causality in any direction. Likewise, Awokuse [6] examines transition European economies and suggests that trade stimulates economic growth; the same applies in another article of the same author [7]that refers on the Japanese economy.

In another cross-border analysis, Silaghi and Ioana [8] examine data from Central and Eastern European countries and find various forms of one-way causality between GDP existing in most cases. Hsiao and Hsiao [9] examine eight rapidly developing Asian economies, i.e. China, Korea, Taiwan, Hong Kong, Singapore, Malaysia, Philippines and Thailand, applying panel data analysis on the relationship between GDP, exports and FDI. They find mixed evidence of unidirectional causality varying from country to country depending also on economic and policy implications.

Finally, in their recent study Sadiku et al. [10]investigate the impacts of the Greek crisis on Western Balkan countries including FYROM by applying a binary logit model than includes variables such as real GDP growth, ratio of domestic bank loans, current account deficit, inflation and budget deficits. The authors conclude that the probability of a systemic crisis and contagion appears higher in countries like FYROM (Albania and Serbia as well) where Greek banks have a strong presence and suggest that policy makers take pre-emptive measures to prevent financial spill-over effects.

\section{Effects on Foreign Effective Demand}

This part of the paper analyses the effects of the Greek crisis on the FYROM foreign effective demand, i.e. FYROM exports to Greece and FYROM total exports. Initially, foreign effective demand is modelled and estimated (in accordance with the methodology of the Central Bank), as a weighted sum of the indices of the gross domestic product of the most important trade partners of FYROM. The weights are calculated based on the participation of these countries in exports. The calculation of the index includes Germany, Greece, Italy, Netherlands, Belgium, Spain and Serbia. In order to determine future foreign effective demand (2012 - 2015) this paper uses estimates of the IMF for GDP in constant prices[11,12].

For the sake of the calculations to evaluate the effects of the Greek crisis on the total FYROM exports and exports to Greece we use the income elasticity coefficient of 1.51 , which is found as a result in the research of the Macedonian Central Bank (Kadievska-Vojnovic and Unesca) as the income elasticity coefficient of FYROM exports in terms of total world GDP. The results of the research from KadievskaVojnovic and Unesca show that income and price elasticity of exports are statistically significant at the $1 \%-5 \%$ level, have the expected signs, and amounted to 1.51 and -0.73 , respectively This means that in the long run, in terms of growth of world income by $1 \%$, the demand for FYROM exports will increase by $1.51 \%$, while relative export prices growth at $1 \%$ will have a decline in exports by $0.73 \%$ (higher domestic prices from foreign prices determine decline in exports). Thus, FYROM exports are more sensitive to changes in world income than price changes. This indicates that the price characteristics of FYROM exports are not the main significant determinant of foreign demand, which is more directed towards non-price (qualitative) aspects of exporting. Thus, if exporters wish to increase their turnover in world markets, they need to increase export non-price aspects (quality, distribution, marketing, etc.)

Given the high concentration of FYROM exports in a few products, mostly for reproduction (iron-steel and their derivatives, petroleum derivatives, as well as clothing and textiles based on a CMT-production), it becomes obvious that it is necessary to invest in qualitative aspects of products in order to attract foreign consumers whose standards grow in accordance with the growth of their income.

In regard to the above (FYROM exports sensitivity to changes in world income rather than price changes) this paper takes into account only the income elasticity of the FYROM exports. The approximation 
of the income elasticity of FYROM exports to Greece is taken the coefficient -1.511, which means in case of decline of Greece's income for $1 \%$, the demand for FYROM exports will decrease by $1.5 \%$ and vice versa. Table 1 summarizes the calculations for foreign effective demand, effective demand by Greece and foreign effective demand without Greece.

Proven from global experience, a small and open economy like that of FYROM cannot reach solid growth rates and operate successfully isolated from its surrounding countries (trading partners and foreign investors). Therefore, the various shocks in the economic and business environment, which is important for our economy, can very easily be transmitted as a spiral to our economy. Exports and FDI (in our economy a significant part comes from private transfers) are the main pillars on which in terms of de facto fixed exchange rate, the stability of the FYROM economy is based. To get a clearer picture of the importance of foreign effective demand (exports) for the FYROM economy Figure 1 shows the movement of real GDP and foreign effective demand in the period from 1999 to 2015 (historical and forecast).

The Figure 1clearly shows the dependence relationship between GDP growth rates and foreign effective demand (before the economic crisis, during the crisis and expected recovery period). From the Figure 1 it can be concluded that by mid-2013 the economy starts recovering, simultaneously with are our major trading partners. This comes as a direct result of the increased exports and positive growth rates of our GDP (specific rates Table 1). During 2012 we witnessed a modest GDP growth, a decline in industrial production and a modest export growth, which was expectable due to the lowest foreign effective demand. But the expectations for 2013 and the following two years are more optimistic, mainly due to the expected positive foreign effective demand in the middle of 2013 and expected higher percentage growth in real GDP (1.9\% in 2013; 3.5\% in 2014 and $4.2 \%$ in 2015).

In addition Figure 2 isolates the effective demand by Greece and shows its movement along with the movement of real GDP of FYROM. Figure 2 also presents a close connection of the movement of the effective demand by Greece and the movement of GDP, but here we can highlight the fact that the Greek effective demand is recovering slower than the Macedonian economy (seen from the GDP perspective). This leads us to the conclusion that the expected economy growth in other major trading partners, will affect our growth rates despite the prolonged economic crisis in Greece. Here we should mention that in decline of Greek effective demand, the strong effect of the economic crisis which presently affects Greek economy is calculated[13].

At a first glance there seems to be little relationship between real change in GDP and the effective demand that comes from Greece. The volatility in our GDP does not seem to closely follow the Greek demand during this period. In order to offer an improved way to view the movement of the total foreign effective demand and effective demand by Greece we report in Graph the following variables: foreign effective demand, foreign effective demand without Greece and effective demand by Greece.

From Figure 3 it becomes obvious that the effective demand that originates from Greece is far below the total foreign effective demand of FYROM. In the period from 2010 - 2011, as well as in the second half of 2013, a clear distinction can be seen between the foreign effective demand and foreign effective demand without Greece, which leads us to the conclusion that the reduced effective demand by Greece would lead to reduction of total foreign effective demand. Especially interesting are the situation in 2012 and the first half of 2013, where foreign effective demand is reduced and has a negative sign, as a result of the enormous cuts of effective demand by Greece. From the overall analysis of this graph it is obvious how much is the negative impact of the Greek contemporary crisis on Macedonia's exports[13].

\section{Two Possible Scenarios}

In order to calculate the effects of the economic crisis from our neighbor country Greece, two scenarios are designed for the period 2012 - 2015 that are most likely to take place in the Greek economy and have strong effects on FYROM's foreign effective demand. The assumptions used to design these two scenarios are Greek GDP growth estimates from the IMF (World Economic Outlook Database), and an income elasticity coefficient of FYROM exports with a value of 1.5 .
GDP on constant prices (real GDP \% changes)

\begin{tabular}{|l|l|l|l|l|l|l|}
\hline Year & Belgium & Germany & Greece & Italy & Netherlands & Spain \\
\hline 1999 & 3.547 & 1.932 & 3.42 & 1.464 & 4.684 & 4.745 \\
\hline 2000 & 3.677 & 3.224 & 4.477 & 3.693 & 3.941 & 5.053 \\
\hline 2001 & 0.807 & 1.151 & 4.197 & 1.818 & 1.926 & 3.645 \\
\hline 2002 & 1.352 & 0.006 & 3.439 & 0.454 & 0.76 & 2.704 \\
\hline 2003 & 0.786 & -0.231 & 5.943 & -0.017 & 0.336 & 3.098 \\
\hline 2004 & 3.091 & 1.176 & 4.623 & 1.532 & 2.237 & 3.267 \\
\hline 2005 & 1.997 & 0.732 & 2.241 & 0.656 & 2.047 & 3.615 \\
\hline 2006 & 2.78 & 3.167 & 4.522 & 2.036 & 3.394 & 4.017 \\
\hline 2007 & 2.843 & 2.517 & 4.472 & 1.482 & 3.613 & 3.563 \\
\hline 2008 & 0.832 & 1.248 & 2.015 & -1.319 & 1.996 & 0.858 \\
\hline 2009 & -3.006 & -4.973 & -1.963 & -5.038 & -3.983 & -3.639 \\
\hline 2010 & 1.153 & 1.21 & -2 & 0.843 & 1.302 & -0.41 \\
\hline 2011 & 1.605 & 1.999 & 0.16 & 1.543 & 1.726 & 1.463 \\
\hline 2012 & 0.037 & 0.936 & -6 & -2.292 & -0.457 & -1.538 \\
\hline 2013 & 0.34 & 0.852 & -4 & -0.73 & 0.394 & -13.16 \\
\hline 2014 & 0.952 & 1.372 & 0 & 501 & 1.353 & 1.004 \\
\hline 2015 & 1.322 & 1.381 & 2.7 & 1.203 & 1.821 & 1.552 \\
\hline
\end{tabular}

Table 1: Foreign effective demand of FYROM (1999-2015)

\begin{tabular}{|l|l|l|l|l|}
\hline & $\begin{array}{l}\text { Foreign effec- } \\
\text { tive demand }\end{array}$ & $\begin{array}{l}\text { Foreign effective } \\
\text { demand from } \\
\text { Greece }\end{array}$ & $\begin{array}{l}\text { Foreign effec- } \\
\text { tive demand } \\
\text { without Greece }\end{array}$ & $\begin{array}{l}\text { GDP in MKD } \\
\text { on constant } \\
\text { prices (real GDP\% } \\
\text { change) }\end{array}$ \\
\hline Serbia & & & & \\
\hline-11.173 & -1.296108872 & 0.511576023 & -1.8076849 & 4.348 \\
\hline 5.254 & 3.085824181 & 0.669685923 & 2.416138258 & 4.539 \\
\hline 5.579 & 2.430780704 & 0.627802506 & 1.802978199 & -4.525 \\
\hline 3.882 & 1.564833335 & 0.514418112 & 1.050415222 & 0.853 \\
\hline 2.448 & 1.517857338 & 0.888975528 & 0.628881809 & 2.82 \\
\hline 8.295 & 3.178218713 & 0.691525133 & 2.48669358 & 4.08 \\
\hline 5.614 & 2.008962967 & 0.335216921 & 1.673746047 & 4.104 \\
\hline 5.213 & 2.846305763 & 0.676417186 & 2.169888576 & 3.903 \\
\hline 6.905 & 3.069998168 & 0.668938005 & 2.401060163 & 5.9 \\
\hline 5.536 & 1.744321367 & 0.30141102 & 1.442910347 & 4.801 \\
\hline-2.873 & -2.515293758 & -0.293632671 & -2.22146109 & -0.9 \\
\hline 1.968 & 0.492960075 & -0.029916727 & 0.79212734 & 2.89 \\
\hline 5 & 1.77693343 & 0.023933381 & 1.753000049 & 3.1 \\
\hline-0.477 & -3.171684049 & -1.276595745 & -1.895 & 0.956 \\
\hline 2.049 & -1.161406114 & -0.85106383 & -0.31 & 1.951 \\
\hline 2.545 & 3.097485948 & 0 & 3.097 & 3.543 \\
\hline 2.2 & 4.846544331 & 0.574468085 & 4.272 & 4.226 \\
\hline & & & & \\
\hline & & & & \\
\hline
\end{tabular}




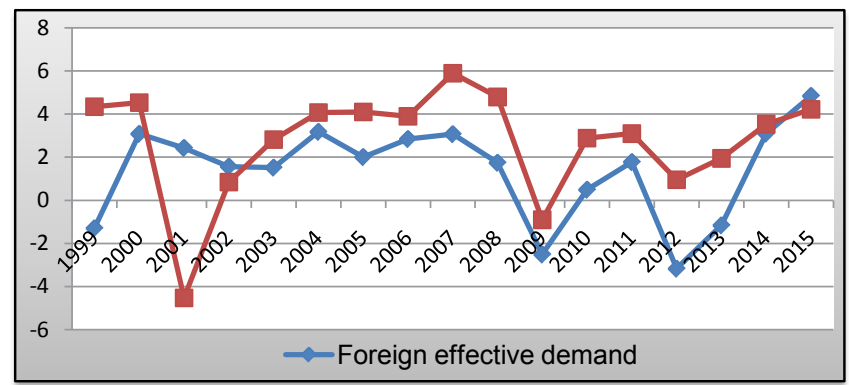

Source: Authors, based on data from IMF - World Economic Outlook Database Figure 1: The interdependence between the real GDP of FYROM and foreign effective demand (1999-2015)

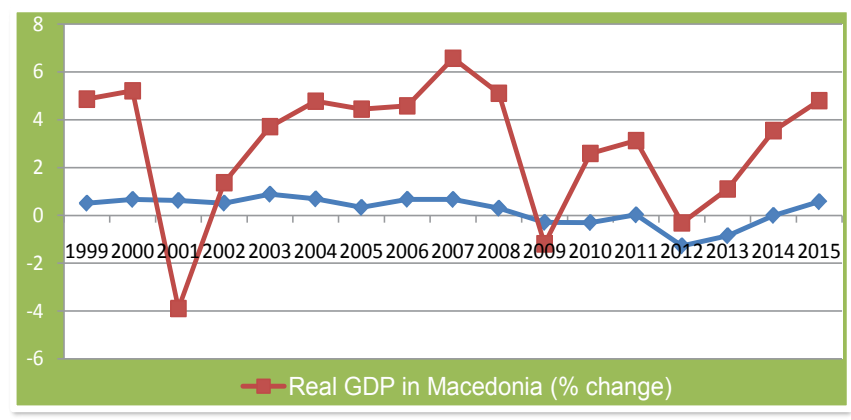

Source: Authors, based on data from IMF - World Economic Outlook Database Figure 2: The interdependence between the real GDP of FYROM and foreign effective demand from Greece (1999-2015)

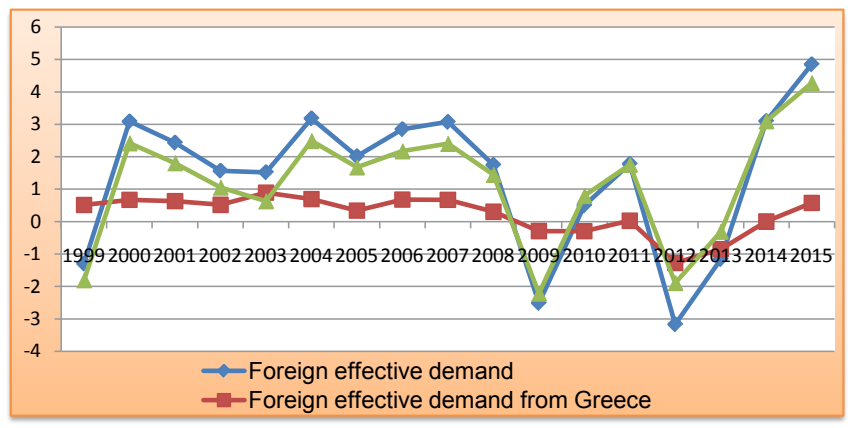

Source: Authors, based on data from IMF - World Economic Outlook Database Figure 3: Foreign effective demand, foreign effective demand without Greece and effective demand by Greece

The first scenario is the reduction of the projected rate of GDP of Greece by 1 percentage point and the ratio of income elasticity of FYROM exports of 1.5 .

Table 2 presents the effects of this scenario on the value of FYROM exports in thousands of U.S. dollars (2012 - 2015), as well as FYROM export growth rates (2012 - 2015). The last column shows the amount of FYROM exports in thousands of U.S. dollars that will be lost if Greece's GDP fell by 1 percentage point below the projected rate, and income elasticity coefficient of FYROM exports stays at 1.5. The first scenario shows that in 2013 the effects of the reduction of the projected rate of Greek GDP by $1 \%$ are not so alarming, but in the following two years, even though the Greek economy starts to recover in 2014 and 2015 at a slower rate in comparison to the decline in 2012 and 2013, the effects will be more noticeable, leading to a loss of 214.69 million USD in 2015 (a figure that is by no way negligible for FYROM economy).

The second scenario is the growth of the projected rate of GDP of Greece by 1 percentage point and the ratio of income elasticity of FYROM exports of 1.5.

Table 3 reports the second scenario with the growth of the projected rate of GDP of Greece at 1 percentage point and the ratio of income elasticity of FYROM exports of 1.5. Table 3 is presenting the effects of this scenario of 1 percentage point of Greek GDP growth on the value of FYROM exports in thousands of U.S. dollars (2012 - 2015), as well as Macedonian export growth rates (2012 - 2015). The last column shows the amount of Macedonian exports in thousands of USD that will be gained if Greece's GDP increase by 1 percentage point above the projected rate of IMF, and income elasticity coefficient of FYROM exports is the same 1.5. This can be better seen at the growth of FYROM exports in 2015, which is 214.69 million USD[14].

Nevertheless, it should be noted that based on the last two tables, the most significant issue is that the growth rate of Macedonian exports presented in USD, when there is $1 \%$ increase in projected Greece GDP growth, is bigger compared to the losses that FYROM exports will have if the Greek GDP fell by $1 \%$. In particular, Figure 4 summarizes this case:

The above shows FYROM exports, in absolute values, in two case scenarios, and in the first scenario there is a decline in the Macedonian exports, and in the second there is a growth in FYROM exports. Analyzing year by year, there is no difference in the numbers considering 2013, but in 2014 there is difference of 1.8 million USD more in growth compared to the decline, taking the absolute numbers. In 2015 there is even bigger difference of about 6 million USD in absolute numbers.

\section{Conclusion}

Although there are signs of recovery and exit from the crisis for some major economies (Germany, France etc.), pace of recovery is with lower intensity than expected, and on the other hand there are economies that are still struggling with the effects of the crisis, such as Portugal, Spain, Italy and many other EU economies.

The effects of the Greek crisis on the total Macedonian exports, according to our analysis are expected to be significant, but not devastating for our economy, taking in consideration the fact that when calculating the effective demand in this paper it was provided only a drop in GDP of Greece. According to the IMF GDP projections for other economies - which are part of our effective demand growth - there will be a smaller, almost insignificant decrease in GDP just in 2012. The IMF projections that were used, assume that growth in other economies will entail greater import demand and thus absorb some of the negative effects of the Greek crisis on the FYROM export. But here comes the question: what will happen and what will be the effect on the FYROM economy be if the effects of the Greek economic crisis spill over into other economies that are major trading partners and investors in FYROM? The answer to this question would go in the direction if there is such a scenario as the Macedonian economy whose GDP growth is highly determined - dependent on foreign effective demand will face a decline in exports, FDI, private transfers, which could lead to pressure on the foreign exchange market, a decline in production, increase in unemployment (which is currently at the highest level in Europe) and devastating meltdown of our economy[15].

The significance of the Greek GDP growth is confirmed with the 
Citation: Davcev L, Hourvouliades N (2013) The Influence of the Greek Economic Crisis on FYROM Exports. J Bus Fin Aff 3:115 doi:10.4172/21670234.1000115

Page 5 of 6

\begin{tabular}{|c|c|c|c|c|c|c|c|}
\hline \multirow[b]{2}{*}{ Year } & \multirow[b]{2}{*}{$\begin{array}{l}\text { GDP growth rates } \\
\text { of the Greek } \\
\text { economy }\end{array}$} & \multirow[b]{2}{*}{$\begin{array}{l}\text { Macedonian export } \\
\text { value (thousand } \\
\text { USD) }\end{array}$} & \multirow[b]{2}{*}{$\begin{array}{l}\text { Macedonian export } \\
\text { growth rate }\end{array}$} & \multicolumn{4}{|c|}{ Scenario for Greek GDP decline by $1 \%$} \\
\hline & & & & $\begin{array}{l}\text { GDP growth rates } \\
\text { of the Greek } \\
\text { economy }\end{array}$ & $\begin{array}{l}\text { Macedonian export } \\
\text { value (thousand } \\
\text { USD) }\end{array}$ & $\begin{array}{l}\text { Macedonian export } \\
\text { growth rate }\end{array}$ & $\begin{array}{l}\text { Decline in Mace- } \\
\text { donian exports }\end{array}$ \\
\hline 2012 & $-6,00 \%$ & 4001857 & $5,00 \%$ & $-7,00 \%$ & 4001857 & 1 & 1 \\
\hline 2013 & $-4,00 \%$ & $4,322,005,777$ & $8,00 \%$ & $-5,00 \%$ & $4,261,977,919$ & $6,50 \%$ & $-6,002,785,801$ \\
\hline 2014 & $0,00 \%$ & $4,746,858,945$ & $9,83 \%$ & $-1,00 \%$ & $4,617,000,679$ & $8,33 \%$ & $-1,298,582,652$ \\
\hline 2015 & $2,70 \%$ & $5,316,482,018$ & $12,00 \%$ & $1,70 \%$ & $5,101,785,751$ & $10,50 \%$ & $-2,146,962,673$ \\
\hline
\end{tabular}

Source: Authors, IMF Country Report 2012

Table 2: Reducing the projected rate of GDP of Greece by 1 percentage points and the ratio of income elasticity of FYROM exports of 1.5

\begin{tabular}{|c|c|c|c|c|c|c|c|}
\hline \multirow[b]{2}{*}{ Year } & \multirow[b]{2}{*}{$\begin{array}{l}\text { GDP growth rates } \\
\text { of the Greek } \\
\text { economy }\end{array}$} & \multirow[b]{2}{*}{$\begin{array}{l}\text { Macedonian export } \\
\text { value (thousand } \\
\text { USD) }\end{array}$} & \multirow[b]{2}{*}{$\begin{array}{l}\text { Macedonian export } \\
\text { growth rate }\end{array}$} & \multicolumn{4}{|c|}{ Scenario for Greek GDP growth by $1 \%$} \\
\hline & & & & $\begin{array}{l}\text { GDP growth rates } \\
\text { of the Greek } \\
\text { economy }\end{array}$ & $\begin{array}{l}\text { Macedonian export } \\
\text { value (thousand } \\
\text { USD) }\end{array}$ & $\begin{array}{l}\text { Macedonian export } \\
\text { growth rate }\end{array}$ & $\begin{array}{l}\text { Growth of Macedo- } \\
\text { nian exports }\end{array}$ \\
\hline 2012 & $-6,00 \%$ & 4001857 & $5,00 \%$ & $-5,00 \%$ & 4001857 & I & I \\
\hline 2013 & $-4,00 \%$ & 4322005,78 & $8,00 \%$ & $-3,00 \%$ & 4382033,63 & $9,50 \%$ & $6,002,785,801$ \\
\hline 2014 & $0,00 \%$ & 4746858,94 & $9,83 \%$ & $1,00 \%$ & 4878518,05 & $11,33 \%$ & $131,659,101$ \\
\hline 2015 & $2,70 \%$ & 5316482,02 & $12,00 \%$ & $3,70 \%$ & 5537117,98 & $13,50 \%$ & $2,206,359,638$ \\
\hline
\end{tabular}

Source: Authors, IMF Country Report 2012

Table 3: Growth of the projected rate of GDP of Greece by 1 percentage points and the ratio of income elasticity of FYROM exports of 1.5

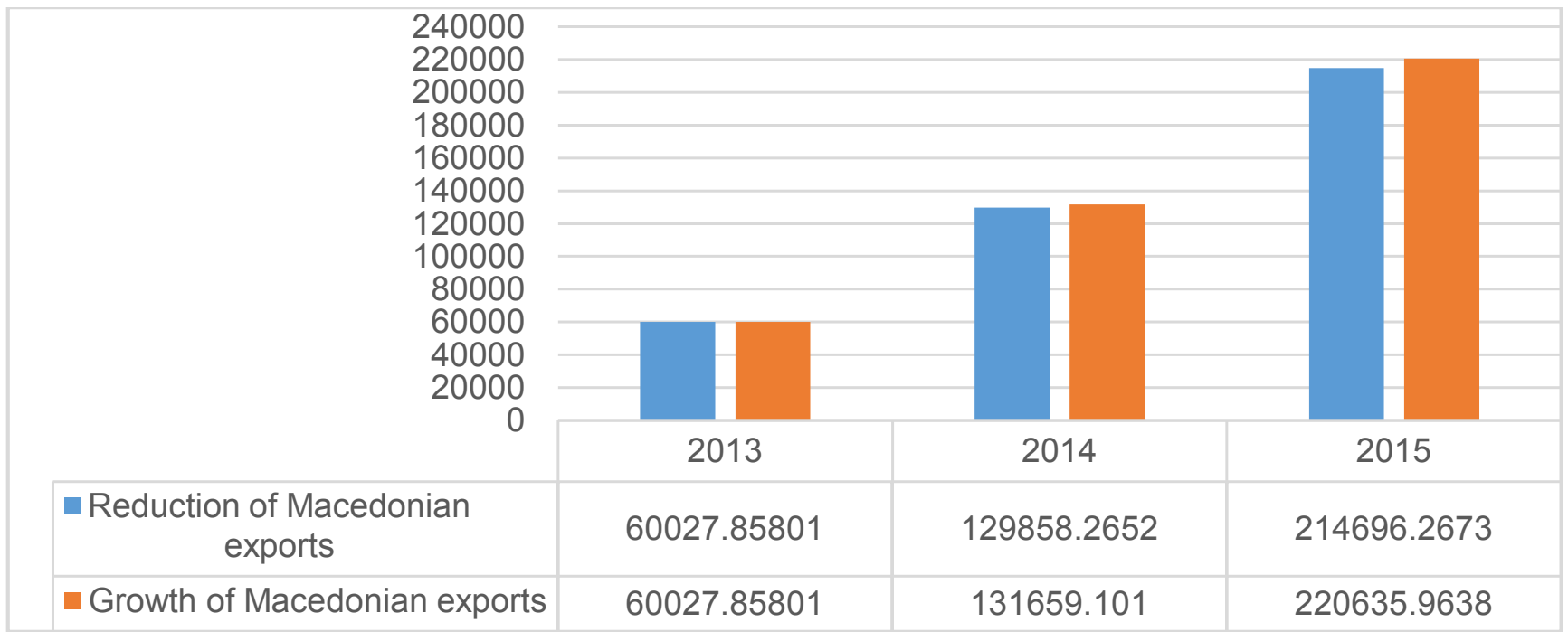

Source: Authors, IMF Country Report 2012

Figure 4: FYROM exports (in absolute values) according to two scenarios (reduction and growth of the projected rate of GDP of Greece by 1 percentage points)

two case scenarios where the increase of Greece GDP growth by $1 \%$ is provoking bigger increase in the FYROM exports, than in the opposite case, where there is $1 \%$ decrease in Greek GDP and smaller decrease in FYROM exports, taking the absolute values of the FYROM exports. Further investigation into the matter should include the inter-related partner economies of FYROM and the potential integrated result that could stem from the different recovery rates of the economies of our partners.

\section{References}

1. Nenovski T, Smilkovski I, Poposki K (2001) Remodeling of the Macedonian Economy. Chinese Business Review 20: 1156-1166

2. Kostoska, O,Petreski, G (2009) Modelling the determinants of Exports and Imports: Assessment of the Macedonian Competitive Performances, Management \& Marketing.

3. Sharma A, Panagiotidis T (2005) An Analysis of Exports and Growth in India: Cointegration and Causality Evidence, Loughborough University working papers.
4. Ramos F (2001) Exports, Imports and Economic Growth in Portugal: evidence from causality and cointegration analysis. Economic Modelling, 18: 613-623.

5. Konya L (2006) Exports and growth: Granger causality analysis on OECD countries with a panel data approach, Economic Modelling 23: 978-992.

6. Awokuse T (2007) Causality between exports, imports and economic growth Evidence from transition economies. Economic Letters, 94: 389-395.

7. Awokuse, T. (2006) Export-led growth and the Japanese economy: evidence from VAR and directed acyclic graphs, Applied Economics, 38(5): 593-602.

8. Silaghi, P. and loana, M. (2009) Exports-Economic Growth Causality: Evidence from CEE Countries, Romanian Journal for Economic Forecasting, 6: 105-117.

9. Hsiao F, Hsiao M (2006) FDI, exports and GDP in East and Southeast Asia Panel Data versus time-series causality analyses. Journal of Asian Economics, 17(6): 1082-1106.

10. Sadiku, M., Sadiku, L. and Berisha, N. (2014) The financial crisis in Greece and its impacts on Western Balkan Countries. Economic Crisis in Europe and the Balkans, Problems and Prospects (eds.) Karasavvoglou and Polychronidou, XII. 
Citation: Davcev L, Hourvouliades N (2013) The Influence of the Greek Economic Crisis on FYROM Exports. J Bus Fin Aff 3:115 doi:10.4172/21670234.1000115

Page 6 of 6

11. International Monetary Fund (2012) Retrieved from IMF Country.

12. International Monetary Fund (2012) World Economic Outlook Database. Retrieved from International Monetary Fund.
13. Basic Economic Data (2012) Retrieved from National Bank of the Republic of Macedonia.

14. Volume of foreign trade (2013) Retrieved from State Statistical Office.

15. EUROSTAT Database (2012) Retrieved from Eurostat.
Citation: Davcev L, Hourvouliades N (2013) The Influence of the Greek Economic Crisis on FYROM Exports. J Bus Fin Aff 3:115 doi:10.4172/21670234.1000115
Submit your next manuscript and get advantages of OMICS Group submissions

\section{Unique features:}

- User friendly/feasible website-translation of your paper to 50 world's leading languages

- Audio Version of published paper

Digital articles to share and explore

Special features:

- 300 Open Access Journals

25,000 editorial team

21 days rapid review process

Quality and quick editorial, review and publication processing

Indexing at PubMed (partial), Scopus, EBSCO, Index Copernicus and Google Scholar etc

- Sharing Option: Social Networking Enabled

- Authors, Reviewers and Editors rewarded with online Scientific Credits

- Better discount for your subsequent articles

Submit your manuscript at: http://www.omicsonline.org/submission 